\title{
Challenges and Adjustments in the Curriculum and Instruction of the K+12 Program: Basis for Strategic Plan
}

\author{
Dr. Gerald A. Quijano
}

Faculty Member, Nueva Ecija University of Science and Technology - Fort Magsaysay Campus, Palayan City, Nueva Ecija, Philippines

Received: 12 Aug 2021; Received in revised form: 06 Sep 2021; Accepted: 16 Sep 2021; Available online: 26 Sep 2021

\begin{abstract}
The Philippines adapted the K+12 program to uplift its educational standards in order to become comparable to those of other countries. RA 10533 was enacted and mandated that all schools both public and private must comply with its provisions/guidelines to better equip its citizens with the necessary knowledge and skills to meet the higher educational demands of life and work of the 21st century. This study assessed the curriculum, instruction, challenges, adjustments, and compliance to the standard of the K+12 program implementation of teachers together with their principal/school heads in the Laboratory High School of Nueva Ecija University of Science and Technology, during the academic year 2019-2020. The study utilized the descriptive method in order to describe the current status of the K+12 curriculum implementation in the said school. A total of 69 respondents were selected through purposive sampling coming from the four campuses of NEUST namely Gabaldon Campus, San Isidro Campus, Fort Magsaysay campus and General Tinio Campus. Weighted means were used to analyze their assessment of the curriculum, instructional-related factors and the challenges and adjustments encountered. The findings showed that the curriculum content, objectives and instructional-related factors are in conformity with the standards, policies or guidelines set by RA 10533, or otherwise known as "Enhanced Basic Education Act of 2013", subject to some improvements due to the addition of elective subjects. Respondents consider their learners as the center of the educational process, use varied types of teaching strategies and techniques depending upon the learners need, and has individual, paired or group applications. Resource materials and facilities are available but they are not adequate, nonetheless, school environment is generally conducive to learning. No significant relationship exists on their assessments with respect to the challenges experienced and the adjustments made in the implementation of the $K+12$ curriculum.
\end{abstract}

Keywords - K+12 Curriculum, curriculum implementation, $21^{\text {st }}$ century learners, curriculum challenges, curriculum adjustments.

\section{INTRODUCTION}

Education has always been considered a vital factor in achieving the general objectives of national development and progress (Combalicer, 2016). In order to achieve the objectives of education, an instrument that serves as a vehicle of operation is required, that instrument is the curriculum which can be defined as all the learning experiences and intended learning outcomes systematically planned and guided by the school through the reconstruction of knowledge of the cognitive, affective and psychomotor development of the learner (Aneke, Nnabuike, and Otegbulu, 2016).
In the light of the foregoing statements, it can be said that the curriculum is one of the foundational elements of effective schooling and teaching, hence, it is often the object of educational reforms.

Pursuant to such reforms, the Philippine government continuously explores innovative programs and measures to improve the country's educational system (Montebon, 2014). In its effort to effect quality education, it adapted the $\mathrm{K}+12$ program which started in the year 2012-2013 and was made into law by virtue of RA 10533 . It is now on its 5 th year of full implementation. 
The goal of the $\mathrm{K}+12$ program is to create a functional basic education system that would produce productive and responsible citizens equipped with the essential competencies and skills for both life - long learning and employment. This program will enhance the basic education system to full functionality to fulfill basic learning needs of students (Sequete 2015).

To receive basic quality education is a fundamental right guaranteed by the Constitution (Article XIV, Section 1). The implementation of $\mathrm{K}+12$ should be regarded as a serious issue as the curriculum itself. This is because no matter how lofty the curriculum is designed, if it is not effectively implemented, the objective of education cannot

be achieved.

Curriculum implementation entails the interaction of the learner and the curriculum contents under the guidance of the teacher in order to acquire desired knowledge, attitudes, abilities and skills (Aneke et.al, 2016). The learner is therefore the central figure in the curriculum implementation process. Implementation takes place as the learner acquires the planned or intended experiences, knowledge, skills, ideas and attitudes to enable him/her to function effectively and responsibly in a given society (Chaudhary, 2015).

At the basic education level, the Department of Education (DepEd) sets the overall educational standards and mandates standardized tests for the $\mathrm{K}+12$ basic education system, although private schools are generally free to determine their own curriculum in accordance with existing laws and Department regulations.

The Nueva Ecija University of Science and Technology being a recognized tertiary institution in the region needs to abide by this mandate for it caters secondary high school students under its Laboratory High School. Said department is under the supervision of the College of Education. It was established to serve as a training ground for NEUST future educators, for their educational experimentation, educational research, and professional development.

The researcher being a regular faculty member of Nueva Ecija University of Science and Technology came up with the idea of assessing its $\mathrm{K}+12$ curriculum implementation. To be able to find out whether or not, the same is in accordance or in conformity with the standards and objectives set by the $\mathrm{K}+12$ program. Hence, the reason for this study.

\section{METHODOLOGY}

The study utilized the descriptive method in order to describe the current status of the $\mathrm{K}+12$ curriculum This article can be downloaded from here: $w w w . i j a e m s . c o m$ implementation of the school, subject of this study. Accordingly, descriptive research describes a present certain condition (Creswell, 2014). Relatively, such method is deemed appropriate since the study involved survey and description of facts and conditions existing within the school system itself. A total of 69 respondents (teachers with their principal) were selected through purposive sampling coming from the four campuses of NEUST namely Gabaldon Campus, San Isidro Campus, Fort Magsaysay campus and General Tinio Campus. To facilitate data collection, the researcher made use of a scholarly-made questionnaire with closed-ended question so as to allow respondents to appropriately choose their response. Weighted means were used to analyze their assessment of the curriculum, instructional-related factors and the challenges and adjustments encountered. Personal interviews were also conducted to obtain first-hand information. Pearson product moment correlation was used to determine if there exist a significant relationship between their assessment on the challenges experienced and the adjustments made in the implementation of the $\mathrm{K}+12$ curriculum.

\section{RESULTS AND DISCUSSION}

This section provides the presentation of data relevant to the study. Corresponding analysis and interpretation were discussed using the above statistical tools.

Table 1 provides for the mean scores and verbal interpretations of the items pertaining to curriculum content as assessed by the teachers and their principals. Based from their assessment, the first-five items which obtain the highest mean are: It follows the spiral progression approach to ensure continuity of learning; instructional materials selected are based on their suitability to attain the objectives of the lesson; geared towards developing the critical thinking skills of the students; designs activities that develop student creativity and flexibility; and contents are contextualized in the light of the present situation with a weighted mean of 3.95 , $3.91,3.91,3.89$ and 3.89 respectively.

This means the teachers "strongly agree", that the curriculum of NEUST laboratory high school adheres to the provisions of RA 10533 particular under section 5 of the same act. A careful scrutiny of the topics presented in the syllabus of instruction used by the teachers revealed that it jives with those topics listed under the DepEd's curriculum guide, thus, it follows the spiral progression approach of learning content. The various syllabus used per subject provides the students with different types of 
student activities and is dependent upon the lesson to be presented. These includes role playing, brainstorming, peer tutoring, simulation, debate, film viewing, concept mapping, problem solving and many others intended for the development of student creativity and flexibility as well as the enhancement of their critical thinking skills.

\section{Table 1. Assessment of the Respondents on Curriculum}

\section{Content}

\begin{tabular}{|c|c|c|c|c|}
\hline Contents & TWM & VI & PWM & VI \\
\hline $\begin{array}{l}\text { 1) The contents of the curriculum are presented in } \\
\text { chronological order. }\end{array}$ & 3.83 & SA & 3.50 & SA \\
\hline $\begin{array}{l}\text { 2) It follows the spiral progression approach to ensure } \\
\text { continuity of learning. }\end{array}$ & 3.95 & SA & 3.75 & SA \\
\hline $\begin{array}{l}\text { 3) Specific values for a particular subject are } \\
\text { integrated in each topic. }\end{array}$ & 3.80 & SA & 3.00 & A \\
\hline $\begin{array}{l}\text { 4) Contents are contextualized in the light of the } \\
\text { present situation. }\end{array}$ & 3.89 & SA & 3.50 & SA \\
\hline $\begin{array}{l}\text { 5) Abreast with the new trends and issues both for } \\
\text { local and international. }\end{array}$ & 3.81 & SA & 3.00 & A \\
\hline $\begin{array}{l}\text { 6) Instructio } \\
\text { suitability to }\end{array}$ & 3.91 & SA & 3.50 & SA \\
\hline $\begin{array}{l}\text { 7) Geared towards developing the critical thinking } \\
\text { skills of the students. }\end{array}$ & 3.91 & SA & 3.75 & SA \\
\hline ated and revised annually. & 3.72 & SA & 3.50 & SA \\
\hline $\begin{array}{l}\text { 9) Designs project-based learning situations for active } \\
\text { students participation }\end{array}$ & 3.82 & SA & 3.00 & A \\
\hline $\begin{array}{l}\text { grates the culture, customs and traditions of } \\
\text { munity }\end{array}$ & 3.86 & SA & 3.25 & A \\
\hline $\begin{array}{l}\text { 11) Creates situations that enable the students to } \\
\text { develop communication skills. }\end{array}$ & 3.83 & SA & 3.50 & SA \\
\hline $\begin{array}{l}\text { 12) Designs activities that develop student creativity } \\
\text { and flexibility. }\end{array}$ & 3.89 & SA & 3.25 & A \\
\hline $\begin{array}{l}\text { 13) Shows no dichotomy between knowledge and } \\
\text { skills. }\end{array}$ & 3.72 & SA & 3.00 & A \\
\hline $\begin{array}{l}\text { 14) Integrates relevant scholarly works and ideas as } \\
\text { needed }\end{array}$ & 3.77 & SA & 2.75 & A \\
\hline $\begin{array}{l}\text { 15) Resources available in the immediate school } \\
\text { environment and community are used to facilitate } \\
\text { learning, hence, "localized". }\end{array}$ & 3.86 & SA & 3.00 & SA \\
\hline Overall Weighted Mean $($ OWM) & 3.84 & SA & 3.28 & SA \\
\hline
\end{tabular}

Legend: WMT - Teacher's weighted mean; WMP - Principal's weighted mean 1.00-1.75 Strongly Disagree (SD); 1.76-2.50 Disagree(D);2.51-3.25 Agree(A);3.26-4.00 Strongly Agree(SA)

Taylor (2004) as cited by Ballesteros (2015) defined contextualization as the development of new skills, knowledge, abilities and attitudes in students when they are presented with new subject matter in a meaningful and relevant context. According to Ballesteros (2015), this was further elaborated by Febby (2011) who defined it as a concept of learning that helps teachers link between the materials taught with real-world situations of students and encourage them to make the connection between the knowledge possessed by its application in their lives as family members and in the community.

The curriculum implementation of the NEUST laboratory high school as observed at the school level encourages students to become active and proactive members of the community through their acquired learning experience in and out of the classroom as evidenced by the various activities used by the teachers. This allows students to get in touch with the real-life issues and to be exposed with real life situations and problems.

To illustrate, students are allowed to perform different extracurricular activities like sports, quiz bee and research competitions in order to boost their morale at the same time allowing them to become more competitive. They are also encouraged to join different student group or organizations like the "HSTAG" which stands for "High School Theatre Arts Group, GSP/BSP scouts, Campus journalism with the "THE CORE" as their campus official newspaper as well as LSC or the Local Student Council for each campus. These organizations allow the students not only to hone their leadership skills and talents, but also training them on how to become assertive and responsible individuals of the community. Thus, there is no question that the concept of contextualization is being practiced. In addition, this also proves that the curriculum of the laboratory high school adheres to standards and principles enunciated by RA 10533.

It is also worthy to note, that when the teachers are asked with regard to the conduct or celebration of their yearly scheduled activities, they answered that "it was pursuant to the DepEd Order No. 007, s.2019”, though some of those activities were done on a different date." This is to show that the LHS do not deviate from the DepEd's mandate by virtue of such order. In addition, LHS also follows the prescribed lists of subjects intended for educating the junior and senior high school, subject to few exceptions like the addition of elective subjects. When the teachers are asked as to what are those elective subjects taken by the students in addition to their regular subjects, they replied, "they have their computer subject in grade 7 , business mathematics in grade 8, statistics in grade 9 and research in grade 10".

This proves that the students at an early age are given the chance to experience the basics of life necessities such as computer literacy, knowledge of business and financial transactions as well as investigative works. In effect, this would enable students to acquire learned strategies that would help them to thrive in their future.

Meanwhile, the assessment of the principal on curriculum content did not reveal much of a deviation from the assessment of the teachers as evidenced from the computed overall weighted mean of 3.28 which is verbally interpreted as "strongly agree".

This means that their responses are consistent with those of the teachers in terms of their assessment on curriculum content that it was aligned with the DepEd's curriculum guide and was made in accordance with the provisions of RA 10533. The difference in their choices among the items listed can be attributed from the difference of their 
functions performed in school. Teachers are more on instruction, research and extension while their principal is focused more on supervisory functions.

Table 2. Respondents' Assessment on Curriculum Objectives

\begin{tabular}{|c|c|c|c|c|}
\hline Objectives & TWM & VI & PWM & VI \\
\hline 1) The objectives are clear and concise. & 3.98 & SA & 3.50 & SA \\
\hline 2) They are measurable, attainable and time bound. & 3.89 & SA & 3.50 & SA \\
\hline $\begin{array}{l}\text { 3) They are basically designed to respond to the } \\
\text { current needs of our country. }\end{array}$ & 3.83 & SA & 3.00 & SA \\
\hline 4) The objectives are student oriented. & 3.94 & SA & 3.75 & SA \\
\hline $\begin{array}{l}\text { 5) The Objectives are geared towards the realization } \\
\text { of national goals and aspirations. }\end{array}$ & 3.82 & SA & 3.25 & SA \\
\hline $\begin{array}{l}\text { 6) They are realistic and attained with contemporary } \\
\text { needs of the country. }\end{array}$ & 3.71 & SA & 3.00 & SA \\
\hline $\begin{array}{l}\text { 7) Opinion of the students, parents and other } \\
\text { stakeholders are solicited in the formulation of the } \\
\text { objectives. }\end{array}$ & 3.69 & SA & 3.50 & SA \\
\hline $\begin{array}{l}\text { 8) The objectives are assessed and modified once a } \\
\text { year. }\end{array}$ & 3.74 & SA & 3.75 & SA \\
\hline $\begin{array}{l}\text { 9) They are designed to realize the optimum } \\
\text { development of the child. }\end{array}$ & 3.82 & SA & 3.75 & SA \\
\hline $\begin{array}{l}\text { 10) The objectives is in accordance with the } \\
\text { curriculum guide of the K- } 12 \text { program. }\end{array}$ & 3.94 & SA & 3.75 & SA \\
\hline Overall Weighted Mean (OWM) & 3.84 & SA & 3.48 & SA \\
\hline
\end{tabular}

Legend: TWM - Teacher's weighted mean; PWM - Principal's weighted mean1.00-1.75 Strongly Disagree(SD);1.76-2.50 Disagree(D);2.51-3.25 Agree(A);3.26-4.00 Strongly Agree(SA)

Table 2 shows the mean scores and verbal interpretations of the items relating to curriculum objectives as assessed by the respondents. Based from the assessment of teachers, the first-five items which obtain the highest weighted mean are: The objectives are clear and concise; the objectives are in accordance with the curriculum guide of the K-12 program; They are measurable, attainable and time bound; The objectives are student oriented; and they are basically designed to respond to the current needs of our country where all are interpreted as "strongly agree".

A careful analysis of the objectives used by the respondents on each lesson as reflected on their syllabus of instruction reveals that it is well-defined and unambiguous. It is directed for the attainment of one key outcome. It is learner-centered, realistic and achievable. It is performed within a certain time-frame and suitably resourced which means that resources include access to individuals with relevant skills and knowledge, as well as the necessary tools needed for knowledge and skill enhancement.

Next from the listed items are the following assessments based on the weighted mean value: The objectives are assessed and modified once a year; They are designed to realize the optimum development of the child; The Objectives are geared towards the realization of national goals and aspirations; they are realistic and attained with contemporary needs of the country; they are designed to realize the optimum development of the child and Opinion of the students, parents and other stakeholders are solicited in the formulation of the objectives.

The overall weighted mean of 3.84 on the part of the teachers which was strongly confirmed by the computed overall weighted mean of 3.48 with that of their principal suggests that, the respondents "strongly agree" that all these characteristics are deemed incorporated within the NEUST's educational goals, given the fact that it is already a well-established and known tertiary institution in the region, with good reputation in producing good quality graduates.

The objectives of the Laboratory High School Department are hereby stated, to wit: Provide high quality standard of teaching with emphasis to Science, Math, and English; Provide opportunities for the acquisition of knowledge and skills which help develop the student total personality and equip them to their part as active members of the community; Train the student to work independently and to think critically, thus, applying the principle of selfactivity; Equip students with advanced general knowledge that will enable them to cope with the college task; Develop and inculcate within the student positive human values and productivity skills necessary to nation building; Provide competent students who will contribute towards the transformation of society into a more just and humane society; Provide training and assistance to student teachers' during their in-campus observation, participation and practice teaching activities; and Encourage and maintain relevant research and barangay-based extension service programs involving faculty and students.

As reflected under Table 3, the following assessments have been observed: Considers the learner as the center of educational process, recognize his/her student learning styles and needs of each individual learner are prioritized in the selection of subject matter, all obtained the highest weighted mean of 3.95, followed by, uses student-based knowledge on subject matter as spring board for discussion with a weighted mean of 3.94, Recognize each learner as unique individuals, Recognize the learner's physical, mental, and emotional development both with weighted mean of 3.92. All are interpreted as "strongly agree".

It can be observed based from the responses that the teachers are very aware with regard to the concept that the learner is the center of educational process and is the primary factor to be considered in the implementation of the curriculum (Chaudhary 2015). In addition, recognition of the learners learning style suggests that different learners learn differently, therefore it is necessary that they must be exposed with varied classroom activities depending on their needs. Equally important is the 
incorporation of the learner's ideas and suggestions during classroom discussions in order to encourage classroom participation.

Table 3. Assessment of the Items in Relation to the Learner as one of Instructional-related Factors

\begin{tabular}{|c|c|c|c|c|}
\hline The Learner & TWM & VI & PWM & VI \\
\hline $\begin{array}{l}\text { 1) Considers the learner as the center of } \\
\text { educational process. }\end{array}$ & 3.95 & SA & 3.75 & SA \\
\hline $\begin{array}{l}\text { 2) Employs student groupings in accomplishing } \\
\text { projects. }\end{array}$ & 3.89 & SA & 3.25 & SA \\
\hline 3) Recognize each learner as unique individuals. & 3.92 & SA & 3.75 & SA \\
\hline $\begin{array}{l}\text { 4) Exposes students to the resources of } \\
\text { community. }\end{array}$ & 3.71 & SA & 3.00 & SA \\
\hline $\begin{array}{l}\text { 5) Needs of each individual learner are prioritized } \\
\text { in the selection of subject matter. }\end{array}$ & 3.95 & SA & 3.50 & SA \\
\hline $\begin{array}{l}\text { 6) The universal and individual characteristics of } \\
\text { learners are considered. }\end{array}$ & 3.82 & SA & 3.50 & SA \\
\hline $\begin{array}{l}\text { 7) Uses student-based knowledge on subject } \\
\text { matter as spring board for discussion. }\end{array}$ & 3.94 & SA & 3.00 & SA \\
\hline $\begin{array}{l}\text { 8) Recognize the learner's physical, mental, and } \\
\text { emotional development. }\end{array}$ & 3.92 & SA & 3.50 & SA \\
\hline 9) Establish good relationships to his/her students. & 3.72 & SA & 3.25 & SA \\
\hline 10) Recognize his/her student learning styles. & 3.95 & SA & 3.50 & SA \\
\hline Overall Weighted Mean (OWM) & 3.88 & SA & 3.40 & SA \\
\hline
\end{tabular}

Legend: TWM - Teacher's weighted mean; PWM - Principal's weighted mean 1.00-1.75 Strongly Disagree(SD);1.76-2.50 Disagree(D);2.51-3.25 Agree(A);3.26-4.00 Strongly Agree(SA)

The views of the teachers with respect to the learners do not contradict with the views of the principal as evident from the obtained overall weighted mean of 3.40 which is interpreted as "strongly agree". This was in accordance with the view of Muring (2014) on the significant role played by the principal as the key leader of our educational system. As the key leader they must be deeply concerned with the success of each student and to ensure that quality basic education is being provided by the school. In other words, the principal is very much aware that they need to collaborate with their teachers and to work with them as a team so that the needs of their individual learner are addressed.

Table 4 presents the weighted means and verbal interpretations of the items relating to the teaching strategies/techniques used, as one of the identified instruction-related factors. The following assessments were obtained: Use varied types of teaching strategies designed to suit the needs of the new curriculum; Give clear and specific directions and emphasize the values to be internalized during learning activities; Employ more innovative techniques such as portfolio to make learning more output -based; Present lessons logically and sequentially and supports them with concrete examples; and Employ effective motivational techniques to sustain pupils' interest in the lessons, with their corresponding

This article can be downloaded from here: $\underline{w w w . i j a e m s . c o m}$ weighted means of $3.93,3.87,3.83,3.80$, and 3.67 all interpreted as "strongly agree".

\section{Table 4. Assessment of the Items in Relation to the Teaching Strategies/Techniques Used}

\begin{tabular}{|c|c|c|c|c|}
\hline Teaching Strategies/Techniques & TWM & VI & PWM & VI \\
\hline $\begin{array}{l}\text { 1) Does team teaching to bring about effective } \\
\text { teaching. }\end{array}$ & 3.47 & SA & 3.75 & SA \\
\hline $\begin{array}{l}\text { 2) Invites resource speakers to share expertise in the } \\
\text { subject matter. }\end{array}$ & 3.21 & A & 3.00 & A \\
\hline $\begin{array}{l}\text { 3) Use varied types of teaching strategies designed } \\
\text { to suit the needs of the new curriculum. }\end{array}$ & 3.93 & SA & 3.75 & SA \\
\hline $\begin{array}{l}\text { 4) Employ more innovative techniques such as } \\
\text { portfolio to make learning more output -based. }\end{array}$ & 3.83 & SA & 3.75 & SA \\
\hline $\begin{array}{l}\text { 5) Make use of every possible resource to improve } \\
\text { them professionally, most particularly in terms of } \\
\text { instruction. }\end{array}$ & 3.50 & SA & 3.25 & A \\
\hline $\begin{array}{l}\text { 6) Enhance teaching through the use of research- } \\
\text { informed strategies. }\end{array}$ & 3.49 & SA & 3.75 & SA \\
\hline $\begin{array}{l}\text { 7) Incorporates student practical experiences with } \\
\text { the lessons. }\end{array}$ & 3.67 & SA & 3.50 & SA \\
\hline 8) Taps community as a learning laboratory. & 3.66 & SA & 3.50 & SA \\
\hline $\begin{array}{l}\text { 9) Consults with experts on the proper } \\
\text { implementation of } \mathrm{K}+12 \text {. }\end{array}$ & 3.20 & A & 3.00 & A \\
\hline $\begin{array}{l}\text { 10) Employs student groupings in accomplishing } \\
\text { projects. }\end{array}$ & 3.52 & SA & 3.50 & SA \\
\hline $\begin{array}{l}\text { 11) Employ effective motivational techniques to } \\
\text { sustain pupils' interest in the lessons. }\end{array}$ & 3.67 & SA & 3.75 & SA \\
\hline $\begin{array}{l}\text { 12) Present lessons logically and sequentially and } \\
\text { supports them with concrete examples. }\end{array}$ & 3.80 & SA & 3.50 & SA \\
\hline $\begin{array}{l}\text { 13) Phrase simple questions that encourage pupil's } \\
\text { participation. }\end{array}$ & 3.54 & SA & 3.50 & SA \\
\hline $\begin{array}{l}\text { 14) Give detailed and redundant explanations for } \\
\text { difficult points. }\end{array}$ & 3.61 & SA & 3.00 & A \\
\hline $\begin{array}{l}\text { 15) Direct discussion effectively and allow pupils to } \\
\text { participate in the discussion. }\end{array}$ & 3.63 & SA & 3.75 & SA \\
\hline $\begin{array}{l}\text { 16) Give clear and specific directions and emphasize } \\
\text { the values to be internalized during learning } \\
\text { activities. }\end{array}$ & 3.87 & SA & 3.75 & SA \\
\hline Overall Weighted Mean (OWM) & 3.60 & SA & 3.50 & SA \\
\hline
\end{tabular}

Legend: TWM - Teacher's weighted mean; PWM - Principal's weighted mean 1.00-1.75 Strongly Disagree(SD);1.76-2.50 Disagree(D);2.51-3.25; Agree(A);3.26-4.00 Strongly Agree(SA)

Finding application on the view of Armstrong (2013) pertaining to the importance of teaching strategies, and the idea of Alsubiae (2016) relating to the role of teachers as the most important person in the curriculum implementation process, there is no question that in the field of teaching profession, teaching strategies and techniques are factors which serves as the means through which the desired objectives of the curriculum is attained, and the effectiveness of such means depends upon the ability of the teachers who employs it in the real classroom situation. Thus, the ability of the teachers to use effective strategies brings successful learning outcomes.

Further examination on the different syllabus of instruction used in the different subjects reveals that teachers of LHS employs different types of strategies or techniques with individual, paired or group applications. Aside from the previously mentioned, the following are also included: practice/board work, pair activity, recall, problem solving, cooperative learning, exposition, drill exercises, question and answer, discovery learning, peer tutoring, field studies, 
jigsaw, buzz session, symposium, simulation, dialogue, group/individual reporting, interview, socialized recitation, round table conference, mnemonics strategy and still many others.

From the perspective of curriculum implementation, the use of various types of strategies merely indicates the flexibility of the curriculum in dealing with different types of learning situations in order to upgrade their students' abilities and the capacities to learn. The giving of clear and specific directions towards the attainment of the goals for a particular learning task lies upon the teacher who served as the facilitator. Equally important are the internalization of values associated for each learning task so that students will appreciate the lessons and its applications in the real world to where he lives. The use of innovative strategies such as portfolios is also used. Most teachers require their students to submit their respective portfolios at the end of each grading period as evidence of their skills and abilities thereby enhancing their creativity. On the same note the use of concrete examples during classroom discussions allows the students to reflect upon themselves the lessons learned and relate it to the actual world. Finally, motivational techniques are basic concepts in the teaching and learning process. The teacher can use either intrinsic or extrinsic motivation to increase student's interest.

The overall all weighted mean of 3.60 which is interpreted as "strongly agree" would mean that the respondents are in favor of the different mentioned strategies. As the need arises, each or a combination of those strategies can be used by them in order to effectively deliver curricular instruction.

Again, the assessment of the principal with regard to the teaching strategies validates the assessment of the teachers based from the computed overall weighted mean of 3.50 interpreted as "strongly agree". The view of Fink and Resnick (2001) as cited by Bodnarchuk (2016) finds application in this particular case since it deals about the principal's responsibilities in supporting quality instruction. This is attained by ensuring that the curriculum is properly implemented and that the delivery of quality instruction must be maintained. By immersing themselves in all aspects of the school system, principals need to monitor daily activities, as well as emerging issues arising from student-teacher conflicts. In the real classroom setup, this can be achieved by the conduct of classroom observation to ensure that the teachers are in the right direction of implementing the curriculum.

Table 5 presents the weighted mean and verbal interpretations of the items relating to the resource materials and facilities available, which are identified as another instruction-related factor.

Based from the results of their assessments, the first-five items with the highest weighted mean are: Use instructional materials to motivate and sustain the varied interests of the pupils; Select instructional materials that are consistent with pupils' capabilities and learning styles; Provision of computer rooms with internet facility; Provides 1:1 ratio of textbooks in every subject; and Uses projector and ICT-related materials in teaching with their weighted means of $3.98,3.98,3.87,3.87$ and 3.83 , respectively, and interpreted as "strongly agree".

Table 5. Assessment of the Items on Resource Materials and Facilities

\begin{tabular}{|c|c|c|c|c|}
\hline Resource Materials and Facilities & TWM & VI & PWM & VI \\
\hline 1) Reads varied references and materials on $\mathrm{K}+12$. & 3.63 & SA & 3.00 & $\mathrm{~A}$ \\
\hline $\begin{array}{l}\text { 2) Collects a variety of learning materials for use in } \\
\text { instruction. }\end{array}$ & 3.66 & SA & 3.75 & SA \\
\hline $\begin{array}{l}\text { 3) Use instructional materials to motivate and sustain } \\
\text { the varied interests of the pupils. }\end{array}$ & 3.98 & SA & 3.50 & SA \\
\hline $\begin{array}{l}\text { 4) Select instructional materials that are consistent } \\
\text { with pupils' capabilities and learning styles. }\end{array}$ & 3.98 & SA & 3.75 & SA \\
\hline $\begin{array}{l}\text { 5)Use mock-ups, realia, models, dioramas and exhibits } \\
\text { to expedite the teaching-learning process. }\end{array}$ & 3.80 & SA & 3.50 & SA \\
\hline $\begin{array}{l}\text { 6) Employs technology-assisted instruction where } \\
\text { appropriate. }\end{array}$ & 3.52 & SA & 3.75 & SA \\
\hline 7) Uses Desktop/laptop computers in teaching. & 3.63 & SA & 3.50 & SA \\
\hline $\begin{array}{l}\text { 8) Uses projector and ICT-related materials in } \\
\text { teaching. }\end{array}$ & 3.83 & SA & 3.75 & SA \\
\hline 9) Provides 1:1 ratio of textbooks in every subject. & 3.87 & SD & 3.50 & A \\
\hline $\begin{array}{l}\text { 10) Provides enough supplies of modules to be used in } \\
\text { all subjects. }\end{array}$ & 3.58 & SA & 3.25 & A \\
\hline $\begin{array}{l}\text { 11) Provides sufficient reference materials in the } \\
\text { library. }\end{array}$ & 3.52 & SA & 3.00 & A \\
\hline $\begin{array}{l}\text { 12) Uses Laboratory rooms/equipment to engage } \\
\text { students to long retention of learning. }\end{array}$ & 3.67 & SA & 3.75 & SA \\
\hline $\begin{array}{l}\text { 13) Uses books and other references in the community } \\
\text { library. }\end{array}$ & 3.53 & SA & 3.00 & A \\
\hline 14) Provides numerous project materials and books. & 3.21 & A & 3.50 & SA \\
\hline 15) Enough number of classrooms. & 3.47 & SA & 3.50 & SA \\
\hline $\begin{array}{l}\text { 16) Provision of pamphlets, magazines, newspapers } \\
\text { and other periodicals in the library. }\end{array}$ & 3.24 & A & 3.50 & SA \\
\hline 17) Provision of computer rooms with internet facility. & 3.87 & SA & 3.75 & SA \\
\hline Overall Weighted Mean (OWM) & 3.65 & SA & 3.48 & SA \\
\hline
\end{tabular}

Legend: TWM - Teacher's weighted mean; PWM - Principal's weighted mean1.00-1.75 Strongly Disagree(SD);1.76-2.50 Disagree(D);2.51-3.25 Agree(A);3.26-4.00 Strongly Agree(SA)

The results of the teacher's assessments merely shows that instructional materials or educational resources is deemed important in order to improve students' knowledge, abilities, and skills, to monitor their assimilation of information, and to contribute to their overall development and upbringing. The initial implementation of the K-12 curriculum did not bring much effect to the NEUST laboratory high school in terms of resource materials and facilities since the same are available in each of its nearby colleges and other departments. The College of Arts and Sciences as well as the College of Education can provide for the laboratory rooms, chemicals and equipment when needed. The College of Industrial Technology with the 
laboratory rooms and materials needed to upgrade their tech-voc skills.

To illustrate, certain science teachers of Gabaldon Campus were asked if they are allowed to use the laboratory rooms of their nearby departments, they replied, "Yes, we are allowed, but we must first seek the permission from the Dean of the college and the laboratory custodian to avoid overlapping of class schedules."

In other words, all these facilities and materials are available in the University and can be used by the students as long as they are permitted upon requests. However, the availability of resource materials cannot be equated to adequacy. The availability of resource materials and facilities from one campus or from one college or department does not necessarily mean that they are also available in another campus, college or department of NEUST. This is made evident based from the previous answers of the respondents that they only "seek permission or requests" to be able to utilize the facilities of other departments when the need arises. In other words, in order to effectively implement the new curriculum, the issue on the "adequacy" of these resource materials and facilities must be resolved. Printed materials such as charts, journals, laboratory guides, modules, textbook and references, and workbooks as well as non-print materials such as computer-assisted instruction, instruction on audio format, instructions on video format, models, documentary films/movies/animations, laboratory equipment and power point presentations must be adequate in the laboratory high school as this is part of enriching or enhancing the curriculum in order to provide the students with meaningful learning experiences.

The use of print and non-print instructional materials and facilities is very important for many reasons. First, people tend not to remember what they are told if they don't have a visual to remember it by (especially if it's information they aren't highly motivated to remember). Second, students who are not academically inclined automatically tune out when a teacher is standing in the front and droning on and on about a topic. When there's something for them to watch, they end up paying attention and becoming engaged (in most cases). Third, students who are not native speakers may have a very difficult time understanding difficult or unfamiliar words, but if they have something visual to see, they can understand the concept and understand the new vocabulary faster.

The use of demos and models allows students to see a variety of equipment being used - some of which they may not have a chance to use themselves. Moreover, incorporation of computers into a specific course can and does add an important level of enhancement. Although not as conclusive as one might hope, studies do indicate that computer use can improve learning and positively influence students' attitudes and self-esteem.

As viewed from the table, the assessment of the principal does not run counter from the assessment of the teachers based from the result of the computed value of the overall weighted mean which is 3.48 that has an interpretation of "strongly agree".

This only suggests that they are fully aware of the importance of these instructional materials and facilities so that the objectives of the new curriculum would be met. In addition, as instructional leaders who has the primary responsibility of ensuring that the new curriculum is properly implemented, it is part of their duty not only to assess the teaching methods employed by the teachers inside the class but also to monitor the teacher's utilization of both their own and the school's resource materials and facilities. In this manner, time and effort is saved on the part of the teachers while their students continuously learn. Thus, by virtue of the appropriate materials used in every class session, the curriculum implementation process becomes suited to the ability and disposition of every child so as to maximize their full potential as learners (Muring 2014).

Table 6. Assessment of the Items on School Environment

\begin{tabular}{|c|c|c|c|c|}
\hline School Environment & TWM & VI & PWM & VI \\
\hline $\begin{array}{l}\text { 1) Maintenance of classroom cleanliness and } \\
\text { orderliness. }\end{array}$ & 3.90 & SA & 3.50 & SA \\
\hline 2) Makes the school environment-friendly. & 3.94 & SA & 3.50 & SA \\
\hline 3) School has established learning centers. & 3.83 & SA & 3.25 & A \\
\hline 4) Strict observance of classroom discipline. & 3.93 & SA & 3.50 & SA \\
\hline $\begin{array}{l}\text { 5) Avoidance of any obstruction that will impede } \\
\text { learning. }\end{array}$ & 3.89 & SA & 3.25 & A \\
\hline Overall Weighted Mean (OWM) & 3.90 & SA & 3.40 & SA \\
\hline
\end{tabular}

Legend: TWM - Teacher's weighted mean; PWM - Principal's weighted mean 1.00-1.75 Strongly Disagree(SD);1.76-2.50 Disagree(D);2.51-3.25 Agree(A);3.26-4.00 Strongly Agree(SA

Table 6 presents the mean scores and verbal interpretations of the items relating to the school environment, another instructional-related factor.

Based from the results of their assessments, the five items with the highest weighted mean are: Makes the school environment-friendly; Strict observance of classroom discipline; Maintenance of classroom cleanliness and orderliness; Avoidance of any obstruction that will impede learning and School has established learning centers which has an overall weighted mean of 3.90 and interpreted as "Strongly Agree".

This only means that a positive school atmosphere encourages student attendance motivates them and allowing them to become more engaged a factor that helps 
cure many of the school woes. It also helps reduce stress for both teachers and students at the same time boosts a more positive mindset for everyone involved. Some studies even suggest that school climate is a key factor in student achievement and teacher retention. When the teachers are asked as to how important the school environment is in facilitating the learning process, they replied, "it is their second home, and we treat them as our own children. As much as possible, we have to maintain the school's friendly atmosphere so they will feel more secured, loved and focused. In this manner they will become more motivated and become participative."

Here, the idea of Wegner, et.al (2013) is applicable. If the teacher considers the learner's motivation and emotions as central condition for successful learning, it can promote active participation and a feeling of social integration.

It can be gleaned also from the table that the assessment of the principal does not negate with the assessment of the teachers as evidenced from the computed overall weighted mean of 3.40, which means that they "strongly agree" with their teacher's views that the school environment must be conducive to the child's learning development or progress. The results can also be attributed to the fact that, teachers and principals need to collaborate with each other in order to bring out the best quality service to their learners.

It is also worthy to note that from the principal's perspectives, the items listed under Table 6 are premised on an ideal learning environment through which the principal must be deeply concerned in order to carry out the school's educational goals, by instilling student conduct and discipline strategies that results in a positive environment conducive to student learning.

As reflected from the table, the average weighted mean obtained was 3.92 which are interpreted as "Strongly Agree". All the following items are applications of the provisions of RA 10533 under section 5, par.(c) which mandates that the curriculum must be "culture-sensitive". The laboratory high school conforms to this required standard. The teachers are not allowed to foster any form of discrimination against any students, or parents by reason of his/her race, color, religion, sex, national origin, age, ancestry, marital status, or him being handicapped. The school is open for all students subject to school policies on student admission.

Table 7. Assessment of the Items on Culture and Ideology

\begin{tabular}{lcccc}
\hline Culture and Ideology & TWM & VI & PWM & VI \\
\hline $\begin{array}{l}\text { 1) Integrates the culture, customs and traditions of } \\
\text { the community. }\end{array}$ & 3.88 & SA & 3.50 & SA \\
$\begin{array}{l}\text { 2) Avoidance of any form of cultural } \\
\text { discrimination. }\end{array}$ & 3.92 & SA & 3.25 & A \\
$\begin{array}{l}\text { 3) Student's ideas and opinions are } \\
\text { respected/recognized. }\end{array}$ & 3.91 & SA & 3.25 & A \\
$\begin{array}{l}\text { 4) Fosters cultural sensitivity during class } \\
\text { interaction. }\end{array}$ & 3.98 & SA & 3.50 & SA \\
$\begin{array}{l}\text { 5) Shows respect to his/her student's religious } \\
\text { belief systems. } \\
\text { Overall Weighted Mean (OWM) }\end{array}$ & 3.89 & SA & 3.25 & A \\
& 3.77 & SA & $\mathbf{3 . 3 5}$ & SA \\
\hline
\end{tabular}

Legend: TWM - Teacher's weighted mean; PWM - Principal's weighted mean 1.00-1.75 Strongly Disagree(SD);1.76-2.50 Disagree(D);2.51-3.25 Agree(A);3.26-4.00 Strongly Agree(SA)

The teacher's assessment is validated by the assessment of their principal based from the computed overall weighted mean of 3.35 which is interpreted as "strongly agree".

The study of Squires (2015) is applicable in this particular case where she highlighted the role of principal as instructional leaders in facilitating curriculum change through which a positive school culture and the reflective practices of school leaders becomes a factor in influencing its implementation. Since the culture and ideology of the principal adheres to those of their teachers, it creates a positive school environment in the LHS where students can see and feel as they enter the school building. When there is no showing of unfair treatment or any form of discrimination, there is an assurance that the students are in good hands and they can fully develop themselves into successful individuals with the aid of their teachers.

Table 8. Assessment of the Items on Instructional Supervision and Assessment

\begin{tabular}{lcccc}
\hline Instructional Supervision and Assessment & TWM & VI & PWM & VI \\
\hline $\begin{array}{l}\text { 1) Reinforce and enhance teaching practices to } \\
\text { improve student learning. }\end{array}$ & 3.92 & SA & 3.25 & A \\
$\begin{array}{l}\text { 2) Provide meaningful feedback and direction to } \\
\text { students }\end{array}$ & 3.94 & SA & 3.25 & A \\
$\begin{array}{l}\text { 3) Guides/facilitates students for every learning } \\
\text { task. }\end{array}$ & 3.98 & SA & 3.25 & A \\
$\begin{array}{l}\text { 4) Uses varied assessment tools to rate student's } \\
\text { performance. }\end{array}$ & 3.89 & SA & 3.75 & SA \\
$\begin{array}{l}\text { 5) Employ formative and summative assessment } \\
\text { measures. }\end{array}$ & 3.87 & SA & 3.50 & SA \\
Overall Weighted Mean (OWM) & $\mathbf{3 . 9 2}$ & SA & $\mathbf{3 . 4 0}$ & SA \\
\hline
\end{tabular}

Legend: TWM - Teacher's weighted mean; PWM - Principal's weighted mean .00-1.75 Strongly Disagree(SD);1.76-2.50 Disagree(D);2.51-3.25 Agree(A);3.26-4.00 Strongly Agree(SA)

Table 8 presents the assessment of the teachers and their principal in relation to instructional supervision and assessment as one of the identified instructional-related factors.

Based from the results of the teacher's assessments, the five items which obtained the highest mean were: Guides/facilitates students for every learning task; Provide 
meaningful feedback and direction to students; Reinforce and enhance teaching practices to improve student learning; Uses varied assessment tools to rate student's performance and employ formative and summative assessment measures. The overall weighted mean of 3.92 tells us that the teachers "strongly agree" with the above listed items. The first three pertains to the teacher as the facilitator of learning.

The words of Maria Wilson-Portuondo find application on this particular aspect. According to her, "A caring adult can make a big difference in the educational outcome of any child that is at risk of experiencing educational failure."

As facilitator of learning, teacher should stop or must not act or operate under the traditional concept of teaching, but rather is meant to guide and assist students in learning in addition to the love and care that they foster to them. Again, this is not a problem for the laboratory high school teachers since most of them were already married and in their middle adulthood stage, and thus, can properly nurture and act as their second parents.

With regard to their assessment of student performance, the teachers stated that "they are aware of DepEd order no.8, s. 2015." which provides for policy guidelines on classroom assessment for the K-12 program. When the teachers are asked if the laboratory high school is also subject to the summative assessment given by DepEd, they replied, "Yes, the students take up their NCAE which stands for National Career Assessment Examination. We also submit to the Department of Education our school profile, and various school forms such as forms 1,2,5,9 and 10." This only proves that aside from being monitored by DepEd, the laboratory high school can also keep track of its student's overall performance through these types of examinations. Speaking of overall performance, it was not stated by the respondents that the laboratory high school students have been consistently performing well in their summative examinations.

The principal's assessment do not run counter from their counterpart teachers based from the computed overall weighted mean of 3.35, which is interpreted as "strongly agree". Chin Chen (2018) provides us the view of instructional supervision based from the principal's perspective. According to him, principals do not only play administrative roles but they also need to instruct teachers. In particular, principals should inspire teachers to overcome challenges and changes in education. Principals who are school leaders should consider the influence of teachers' instructional behaviors while emphasizing their own roles in instructional supervision.
This means that in order to positively affect teachers' instructional quality, principals must engage teachers in various activities that would improve their instructional practice and strategies as well as to empower them to become creative and innovative. This can be done by engaging teachers in instructional dialogue and reflective performance to ensure that they are thoroughly equipped to improved student performance. Establishing good communication and relationship with them is another way of gaining their trust and confidence. The same concept is also applicable on student assessment in relation to student achievement.

Table 9. Respondents' Assessment of the Items on the Challenges Experienced

\begin{tabular}{|c|c|c|c|c|}
\hline Challenges & TWM & VI & PWM & VI \\
\hline $\begin{array}{l}\text { 1) Lack of proper initiatives to generate school } \\
\text { funds/income. }\end{array}$ & 1.22 & SD & 2.00 & $\mathrm{D}$ \\
\hline $\begin{array}{l}\text { 2) Failure of the parents and other stakeholders in the } \\
\text { community to give voluntary contributions. }\end{array}$ & 1.34 & SD & 2.00 & $\mathrm{D}$ \\
\hline $\begin{array}{l}\text { 3) Failure to initiate proper solicitations from selected } \\
\text { persons/individuals such as politicians, or other } \\
\text { organizations such as NGO's, local and abroad. }\end{array}$ & 1.52 & SD & 1.75 & SD \\
\hline 4) Mismatched of teacher qualifications. & 1.02 & SD & 1.25 & SD \\
\hline 5) Lack of mastery on the subject being taught. & 1.06 & SD & 1.25 & SD \\
\hline $\begin{array}{l}\text { 6) Insufficient number of seminars and workshops } \\
\text { attended related to K-12. }\end{array}$ & 1.68 & SD & 1.50 & SD \\
\hline 7) Lack of proper training and skills. & 1.60 & SD & 1.25 & SD \\
\hline 8) Unbalanced student to teacher ratio. & 1.68 & SD & 1.50 & SD \\
\hline $\begin{array}{l}\text { 9) Lack of knowledge, skills, proper attitudes and } \\
\text { values pertinent to } K+12 \text {. }\end{array}$ & 1.05 & SD & 1.75 & SD \\
\hline $\begin{array}{l}\text { 10) Poor awareness on the goals, purposes, and } \\
\text { objectives of } K+12 \text {. }\end{array}$ & 1.14 & SD & 1.50 & SD \\
\hline $\begin{array}{l}\text { 11) Failure to engage in research and extension } \\
\text { activities. }\end{array}$ & 1.54 & $\mathrm{SD}$ & 2.00 & $\mathrm{D}$ \\
\hline $\begin{array}{l}\text { 12) Inappropriate attitude and lack of work ethics } \\
\text { fostered by colleagues. }\end{array}$ & 1.48 & SD & 2.00 & $\mathrm{D}$ \\
\hline $\begin{array}{l}\text { 13) Inadequate knowledge on varied teaching } \\
\text { strategies and techniques. }\end{array}$ & 1.08 & SD & 1.25 & SD \\
\hline $\begin{array}{l}\text { 14) Insufficient knowledge on educational } \\
\text { technology. }\end{array}$ & 1.51 & SD & 1.50 & SD \\
\hline $\begin{array}{l}\text { 15) Inadequate knowhow on the use of varied } \\
\text { assessment tools. }\end{array}$ & 1.57 & SD & 1.75 & SD \\
\hline Overall Weighted Mean (OWM) & 1.36 & SD & 1.62 & SD \\
\hline
\end{tabular}

Legend: TWM - Teacher's weighted mean; PWM - Principal's weighted mean; 1.00-1.75 Strongly Disagree (SD);1.76-2.50 Disagree(D);2.51-3.25 Agree(A);3.26-4.00 Strongly Agree(SA)

Based from the results of their assessments, the first-five items which obtained the highest weighted mean were: Mismatched of teacher qualifications; Lack of knowledge, skills, proper attitudes and values pertinent to $\mathrm{K}+12$; Lack of mastery on the subject being taught; Inadequate knowledge on varied teaching strategies and techniques and Poor awareness on the goals, purposes, and objectives of $\mathrm{K}+12$, with their weighted means of $1.02,1.05,1.06$, 1.08 , and 1.14 , all interpreted as "strongly disagree".

Here, the teachers believe that the subjects being taught by them are those that are within their field of specialization. They also disaffirm the notion that they lack proper attitudes, knowledge, skills and teaching strategies given the fact that most of these teachers are already "seasoned 
teachers". Their strong disagreement on poor awareness on the goals, purposes and objectives of $\mathrm{K}+12$ also holds true given the fact that they attended numerous seminars and conferences pertaining to it. Their response to the different items on challenges experienced gained an overall weighted mean of 1.36 , which means that the teachers "strongly disagree" on the idea that the implementation of K-12 curriculum has become a serious issue or big problem within their department.

This was confirmed by their principal since their assessment do not contradict with the assessment of the teachers as evidenced from the computed overall weighted mean of 1.62, which is interpreted as "strongly disagree".

Table 10. Respondents' Assessment of the Items on the Adjustments Made in the Course of the $K+12$ Implementation

\begin{tabular}{|c|c|c|c|c|}
\hline Adjustments & TWM & VI & PWM & VI \\
\hline $\begin{array}{l}\text { 1) Have the initiative to asks local politicians for } \\
\text { financial support. }\end{array}$ & 3.23 & A & 2.75 & A \\
\hline 2) Must have the initiative to ask solicitations from & & & & \\
\hline $\begin{array}{l}\text { PTA, Alumni or other organizations such as } \\
\text { NGO's, local and abroad. }\end{array}$ & 3.33 & SA & 2.75 & A \\
\hline $\begin{array}{l}\text { 3) Proper initiative in designing off and in-campus } \\
\text { activities intended for fund-raising like the conduct } \\
\text { of "color run", auction sale of used goods for a } \\
\text { cause. }\end{array}$ & 3.57 & SA & 3.00 & A \\
\hline $\begin{array}{l}\text { 4) Teacher must assert to teach subjects within } \\
\text { his/her field of specialization. }\end{array}$ & 3.90 & SA & 3.50 & SA \\
\hline $\begin{array}{l}\text { 5) Teachers impart knowledge confidently and } \\
\text { effectively, with the inclusion of important updates } \\
\text { for each topic. }\end{array}$ & 3.87 & SA & 2.75 & A \\
\hline $\begin{array}{l}\text { 6) Must have the drive to attend seminars and } \\
\text { workshops related to K-12. }\end{array}$ & 3.83 & SA & 3.25 & A \\
\hline $\begin{array}{l}\text { 7) Attend relevant K- } 12 \text { trainings to keep abreast of } \\
\text { the modern techniques of teaching and skill } \\
\text { acquisition. }\end{array}$ & 3.95 & SA & 3.50 & SA \\
\hline $\begin{array}{l}\text { 8) Proper scheduling and maximization of room } \\
\text { utilization. }\end{array}$ & 3.33 & SA & 3.25 & A \\
\hline $\begin{array}{l}\text { 9) Must have the initiative to seek administrative } \\
\text { financial support to attend K-12 trainings. }\end{array}$ & 3.23 & A & 3.00 & A \\
\hline $\begin{array}{l}\text { 10) Varied references and materials on } \mathrm{K}+12 \text { are } \\
\text { made accessible. }\end{array}$ & 3.50 & SA & 3.00 & A \\
\hline $\begin{array}{l}\text { 11) Must undertake enough research-based trainings } \\
\text { and workshops and be able to produced quality } \\
\text { outputs. }\end{array}$ & 3.87 & SA & 3.25 & A \\
\hline $\begin{array}{l}\text { 12) Plans and suggest measures to strengthen } \\
\text { organizational relationships. }\end{array}$ & 3.67 & SA & 3.25 & A \\
\hline $\begin{array}{l}\text { 13) They must undergo seminars and workshops on } \\
\text { innovative techniques such as portfolio to make } \\
\text { learning more output-based. }\end{array}$ & 3.33 & SA & 3.75 & SA \\
\hline $\begin{array}{l}\text { 14) Must have knowledge and skills on the use of } \\
\text { multimedia technology in the delivery of } \\
\text { instruction. }\end{array}$ & 3.92 & SA & 3.75 & SA \\
\hline $\begin{array}{l}\text { 15) Trainings on reliable assessment tools and } \\
\text { techniques to evaluate student's performance. }\end{array}$ & 3.87 & SA & 3.50 & SA \\
\hline Overall Weighted Mean (OWM) & 3.63 & SA & 3.22 & $\mathbf{A}$ \\
\hline
\end{tabular}

Legend: TWM - Teacher's weighted mean; PWM - Principal's weighted mean; 1.00-1.75 Strongly Disagree(SD);1.76-2.50 Disagree(D);2.51-3.25 Agree(A);3.26-4.00 Strongly Agree(SA)

This is true since as previously mentioned, the resource materials and facilities as well as the necessary equipment are available to the high school students and are within reach inside the university system. Being available, the quality of education being offered is still maintained. This supports the view of Chaudhary (2015) who pointed out that no meaningful teaching and learning can take place within the school environment without the necessary resource materials and facilities available to the students. Any school system must meet these requirements in order for the curriculum implementation process to be effective.

Table 10 presents the respondents' assessment of the items relating to the adjustments made by the respondents in the implementation of K-12 curriculum.

Based from the results of the computed weighted means, these are: Attend relevant K-12 trainings to keep abreast of the modern techniques of teaching and skill acquisition; Teacher must assert to teach subjects within his/her field of specialization; Must have knowledge and skills on the use of multimedia technology in the delivery of instruction; Teachers impart knowledge confidently and effectively, with the inclusion of important updates for each topic; Trainings on reliable assessment tools and techniques to evaluate student's performance; Must undertake enough research-based trainings and workshops and be able to produced quality outputs; with their weighted means of $3.95,3.92,3.90,3.87,3.87$, and 3.87 all being interpreted as "strongly agree".

The result implies that the laboratory high school teacher's despite in their long years of teaching experience still have that urge and eagerness to learn. This supports the statement that learning is a continuous process. For teachers to deliver quality instruction, they must constantly update and upgrade themselves all for the benefit of their students. The overall weighted mean of 3.67 means that the teachers "strongly agree" to the listed suggested items to be adapted as part of the adjustments for a sound and effective implementation of the K-12 curriculum.

This was evidently confirmed by their principals since their assessment does not deviate with those of the teachers as evidenced from the computed overall weighted mean of 3.22, which is interpreted as "Agree".

The strong adherence of the teachers on the items under Table 10 which was validated by their principal is a clear manifestation that the latter plays a proactive role in supporting their teachers' adaptive efforts in implementing the new curriculum. This was confirmed by the teachers when they stated that their principal frequently interacts with them in a positive manner and on a daily basis dealing with instructional matters. According to them, their principal does not only discuss academic issues, but also, they guided, encouraged, reinforced and promote their instructional efforts. The teachers also made some utterances that their principal sees to it that teaching assignments were matched based on their expertise to ensure that student's needs are met. Moreover, according to the teachers, their principal provides them their instructional needs by allocating them resources and 
materials for the purpose of implementing the new curriculum effectively. The view of Squires (2015) is applicable in the instant scenario as it highlights the cultivation of a strong sustained school culture toward the continuance of school improvement and student achievement while maintaining harmonious principalteacher relationships within the school system.

Table 11. Correlation between their Assessment on the Challenges Experienced and Adjustments Made in the $K+12$ Curriculum Implementation

\begin{tabular}{llcc}
\hline & & Challenges & Adjustments \\
\hline \multirow{4}{*}{ Challenges } & Pearson & 1 & 0.325 \\
& Correlation & & 0.237 \\
& Sig. (2-tailed) & & 15 \\
\hline
\end{tabular}

Table 11 provides for the correlation between the assessment of the respondents on the challenges experienced and the adjustments made in the course of the $\mathrm{K}+12$ curriculum implementation.

Here, it was revealed that there was no significant relationship existing on their assessments as regards to the challenges experienced and the adjustments made where $r$ $=.325$ at $(\mathrm{p}>.05)$. This can be attributed from the fact that the overall weighted mean of 1.36 for challenges experienced "strongly disagrees" with the overall weighted mean of adjustments made which is equal to 3.63, interpreted as "strongly agree". In other words, the respondents in the laboratory high school department did not experience much of the adverse effects brought about by the curriculum change.

To illustrate, the respondents were asked about what are their experiences during the initial implementation of the program, they answered, "There are no bad experiences or challenges whatsoever, we have not run out of equipment and facilities that we use during our laboratories, nor we have been displaced to other schools during the transition period." They added that, "We are familiar with the $K+12$ subjects, since these are the same subjects that we took during our undergraduate and graduate studies. We are only tasked to teach those subjects in line of our field, they claimed."

However, their assessment on adjustments merely implies that the respondents "strongly agree" that the suggested items must be constantly practiced and performed by them so as to effectively implement the new curriculum.

\section{Proposed Strategic Plan for the Effective K-12 Curriculum Implementation}

Objective: This proposed strategic action plan aims not only for the improvement but also for the promotion of the $\mathrm{K}+12$ curriculum implementation, particularly in the laboratory high school department of NEUST.

\section{A. Curriculum Enhancement and Enrichment}

Encourage NEUST administrators to:

1. Develop strategic programs which will establish a sense of urgency among stake- holders in support of curriculum enhancement and use accountability mechanisms to track teachers' performance in delivering an effective and sustainable curriculum.

2. Provide instructional technology hardware for use in curricular integration, record keeping and stakeholder communications

3. Design and implement activities and programs with the intention to lead teachers in Curriculum implementation and to guide them in the preparation of an enriched $\mathrm{K}+12$ curriculum.

4. Identify and adopt current benchmark curriculum models that use pedagogical approaches in line with the $\mathrm{K}+12$ program.

B. Student Development, Engagement and Achievement

1. Upgrade existing infrastructure and resources to support all working and learning environments, as well as the learning needs of students.

2. Assess the current levels of student performance in Science, Mathematics and English subjects to determine their mastery, understanding, and progress in these subjects.

3. Engage and empower students to become more active participants in the learning experiences that are relevant to their lives and the global marketplace.

4. Design and adopt a continuous cycle of programs and activities that encourages student involvement and development.

5. Develop and implement use of a variety of alternate assessment practices that mirror differentiated instructional practices.

\section{Instruction}

1. Enhance or improve instructional materials, learning and teaching aids, learning resources and instructional tools to become more innovative 
thereby increasing student motivation and interests.

2. Intensive use of technology-based instruction to improve teaching quality and effectiveness.

3. Provision of financial support and encouragement for teachers in the pursuance of their postgraduate degrees.

\section{Strengthening Research Culture}

1. Enhance a positive research culture by subjecting faculty members into various Research Capability training programs.

2. Further enhancement of necessary research skills in proposal writing, data-handling, statistical treatment through mentoring and coaching activities by seasoned researchers of the University.

3. Encourage and support the faculty members in the conduct of research presentation and publication in different fora.

4. Promote equal partnerships with other faculty members through research collaboration.

5. Encourage and incentivize Student's Involvement in research works.

6. Investing of research statistical softwares.

\section{CONCLUSIONS AND RECOMMENDATIONS}

In the light of the above-cited findings, it can be inferred that the curriculum in general follows the K-12 curriculum guidelines established by the Department of Education in terms of content. It follows the standards and principles established by the provisions of RA 10533 otherwise known as the "Enhanced Basic Education Act of 2013".

The objectives set by the laboratory high school department are in accordance with its institutional goals and in line with the K-12 program. At the level of instruction, the objectives are specific, measurable, achievable, realistic and time-bound. The effect of curriculum change did not bring much negative impact in the NEUST laboratory high school as claimed by the respondents since the materials, facilities and equipment as well as human resources are available within the university system. The respondents were mindful that the items on adjustments must be faithfully observed and duly implemented in order to satisfy the objectives of the new curriculum. No significant relationship exists on their assessments with respect to the challenges experienced and the adjustments made in the implementation of the $\mathrm{K}+12$ curriculum.
The purpose of RA 10533 will not be met if the national government lacks the genuine support in its implementation. It behooves upon it the provision of sufficient funding intended for all public educational institutions. In the same manner, teachers as the implementer and manager of the curriculum must be competent, creative and innovative in enhancing and enriching the curriculum. It is only then that the delivery of the content of the curriculum is made effective and in addition, the objectives of the law are realized.

In line of the challenges of the new curriculum, teachers must undergo intensive trainings on research and publication. Trainings must be conducted focusing on the use of statistical tools and its applications. The university also must invest on these statistical tools and the faculty researchers must be provided with such. Trainings pertaining to online publication must also be provided.

Teachers must master the competencies and skills in enhancing the curriculum to fit the nature, needs and interests of the learners. It is incumbent upon them to have the expertise to indigenize and localize the curriculum in order to maximize the use of community resources for student projects and research work as well as to make the curriculum appropriate in addressing community needs and the needs of the industry, thus making the curriculum relevant and responsive.

Adjustments in the implementation of the new curriculum is likewise made if the administrators and principals are giving proper incentives to teachers as a form of motivation who write instructional materials in their respective fields of specialization in order to serve as supplemental materials in their teaching tasks. In addition, provisions for upgraded facilities and technology-related equipment must be given preferential attention by school administrators in other campuses of NEUST to promote effective instruction in their respective localities. Moreover, a clear provision on the giving of incentives to teachers and students who are involved in research works must be prioritized to motivate them well to do such scholarly works.

Explore and establish permanent linkages with different stakeholders in the community as well as other educational institutions, business establishments and agencies to act as partners in the effective implementation of the $\mathrm{K}+12$ curriculum. In addition, student orientation campaign regarding the $\mathrm{K}+12$ curriculum may likewise be conducted for them to fully understand its rationale, objectives and importance. These adjustments are necessary for the $\mathrm{K}+12$ 's effective implementation. 


\section{REFERENCES}

[1] Alsubaie, M.A. (2016). Curriculum Development: Teacher Involvement in Curriculum Development. Retrieved from https://files.eric.ed.gov/fulltext/EJ1095725.pdf

[2] Aneke, M.C., Nnabuike E.K., Otegbulu R.I., (2016). Curriculum Implementation and the Teacher: Issues, Challenges and the Way forward. Retrieved from https://www.academia.edu/36331202/curriculum_implement ation and the teacher issues challenges and the way forward

[3] Armstrong, S. (2013). Top 10 Most Important Teaching Strategies. $\quad$ Retrieved from http://www.innovatemyschool.com/ideas/item/446-the-10most-powerful-teaching-strategies.html

[4] Ballesteros, J.O. (2015). Localization and Contextualization of Science Activities in Enhancing Learners' Performance. Retrieved from https://www.academia.edu/26424467/Localization_and_Con textualization_of_Science_Activities_in_Enhancing_Learne rs_Performance

[5] Bodnarchuk, M. (2016). The Role of Principal as Instructional Leader. Retrieved from https://selu.usask.ca/documents/research-and-publications /srrj/SRRJ-1-1-Bodnarchuk.pdf

[6] Chaudhary, J.K (2015). Factors Affecting Curriculum Implementation for Students. Retrieved from http://www.allresearchjournal.com/archives/2015/vol1issue 1 2/PartN/2-5-158-343.pdf

[7] Chin Chen C. (2018). Facilitation of Teachers' Professional Development through Principals' Instructional Supervision and Teachers' Knowledge-Management Behaviors. Retrieved from https://www.intechopen.com/books/contemporarypedagogies-in-teacher-education-anddevelopment/facilitation-of-teachers-professionaldevelopment-through-principals-instructional-supervision

[8] Creswell, J. W. (2014). Research Design: Qualitative, Quantitative and Mixed Methods Approaches (4th Ed.). Thousand Oaks, CA: Sage Publications Ltd.

[9] Combalicer Jr., L.F. (2016). Best Practices and Problems in the Initial Implementation of the $\mathrm{k}+12$ Curriculum among Teachers in Infanta, Quezon: Implications to an Effective Implementation of Senior High School. Retrieved fromhttps://www.jesoc.com/wpcontent/uploads/2016/08/Ed u-4.pdf

[10] Febby, M. (2011). Definition of contextual teaching and learning. Retrieved from https://www.academia.edu/26424467/Localization_and_Con textualization_of_Science_Activities_in_Enhancing_Learne rs_Performance

[11] Fink, E. and Resnick, L. (2001). Developing Principals as Instructional Leaders. The Phi Delta Kappan, 82(8), 598. Retrieved from https://selu.usask.ca/documents/researchand-publications /srrj/SRRJ-1-1-Bodnarchuk.pdf

[12] Montebon, D.R. (2014). K12 Science Program in the Philippines: Student Perception on its Impementation.

Retrieved from https://www.researchgate.net/publication/280234350 K12
Science Program in the Philippines Student Perception on its Implementatio

[13] Muring, J.V. (2014). The Challenging Roles of a School Principal. Retrieved from https://www.depedmalaybalay.net/articles/the-challengingroles-of-a-school-principal.html

[14] Rheinberg, F. (2000): Motivation. Stuttgart, Berlin, Köln: Kohlhammer. Retrieved from https://files.eric.ed.gov/fulltext/EJ1108220.pdf

[15] Sequete, F.R. (2015). A Review on the Issues in the Implementation of K-12 Science Curriculum: A Baseline Study. Retrieved from https://www.researchgate.net/publication/308019509_a_revi ew on the issues in the implementation of k12 science curriculum a baseline study

[16] Squires, T.M (2015). Leading Curricular Change: The Role of the School Principal in Implementation of the Common Core State Standards. Retrieved from

https://surface.syr.edu/cgi/viewcontent.cgi?article=1406\&co ntext=etd

[17] Taylor, E.W. (2004). The theory and practice of transformative learning: a critical review. Journal of Education. (374). Retrieved from https://www.academia.edu/26424467/Localization and Contextualization of Science Activities in Enhancing Learners Performance

[18] Wegner, C., Minnaert L., and Strehlke F. (2013). The Importance of Learning Strategies and How the Project "Kolumbus-Kids" Promotes them Successfully. Retrieved from https://files.eric.ed.gov/fulltext/EJ1108220.pdf 